\title{
Twenty-five-centimeter pre-grazing canopy height in palisade grass and forage peanut
}

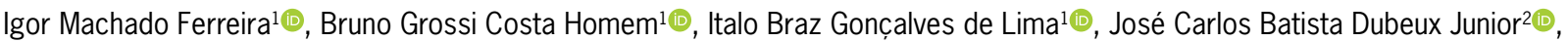 \\ Thiago Fernandes Bernardes ${ }^{1}$, Marina de Arruda Camargo Danés ${ }^{1}\left(\mathbb{B}\right.$, Daniel Rume Casagrande ${ }^{*}$ (1)
}

\begin{abstract}
${ }^{1}$ Universidade Federal de Lavras - Depto. de Zootecnia, C.P. 3037 - 37200-000 - Lavras, MG - Brasil.

¿University of Florida/North Florida Research and Education Center, 3925 Highway, 71 - 32446 - Marianna, FL - USA.

*Corresponding author <danielcasagrande@ufla.br>
\end{abstract}

Edited by: Harley D. Naumann / Paulo Cesar Sentelhas

Received April 03, 2020

Accepted December 17, 2020
ABSTRACT: Short-term grazing behavior variables are sensitive to the canopy structure and have an impact on daily forage intake. This study evaluated the effect of pre- and post-grazing canopy heights on the forage harvesting process at a patch scale in a mixture of Brachiaria brizantha (Hochst. ex A. Rich.) Stapf. syn. Urochloa brizantha R.D. Webster cv. Marandu (palisade grass) and Arachis pintoi Krapov. \& W.C. Greg. cv. Belomonte (forage peanut). Treatments were allocated to a split-plot arrangement in a completely randomized design. The plots, in their entirety, consisted of two pre-grazing canopy heights: $25 \mathrm{~cm}(\mathrm{CH} 25)$ and $35 \mathrm{~cm}(\mathrm{CH} 35)$; subplots consisted of three levels of defoliation severity: no defoliation (DSO); $20 \%$ depletion of pre-grazing canopy height (DS20); and 40\% depletion of pre-grazing canopy height (DS40), with eight replications. Heifers were allowed to graze the patches $(0.7 \times 0.7$ m) and their grazing behavior was recorded. Canopy structure measurements were taken both before and after grazing. Patches from $\mathrm{CH} 35$ presented greater stem mass for grass $(p=0.001)$ and legume $(p=0.002)$ than did patches from $\mathrm{CH} 25$. Bite rate, bite mass and instantaneous intake rate were greater for $\mathrm{CH} 25$ than for $\mathrm{CH} 35(p<0.001, p=0.068$, and $p$ $=0.074$ ), and bite mass and instantaneous intake rate were lower for DS20 compared to DSO ( $p=0.032$ and $p=0.016$ ). Greater stem mass in the grazing strata negatively influenced the instantaneous intake rate.

Keywords: Arachis pintoi, Brachiaria, Urochloa, forage intake, warm-season legume

\section{Introduction}

The canopy structure is continuously changing as a result of plant growth, defoliation, and senescence (Mezzalira et al., 2014). It modulates forage harvesting during the grazing process (Benvenutti et al., 2016). Ungrazed canopies facilitate forage harvesting; however, forage prehension by grazing livestock throughout the occupation period mainly in tropical grass gradually becomes increasingly difficult. Short-term grazing behavior variables are sensitive to the canopy structure and have a pronounced impact on daily forage intake (Carvalho et al., 2015). In rotational stocking, there is typically a decrease in leaf/ stem ratio throughout the stocking period (Fonseca et al., 2013). Consequently, there is a progressive reduction in short-term intake rate and bite volume (Fonseca et al., 2012; Fonseca et al., 2013), which can result in a reduction in daily herbage intake.

In grass monoculture canopies, a reduction in the short-term intake rate was observed when grazing down was higher than $40 \%$ of the pre-grazing canopy height, negatively affecting the forage intake (Fonseca et al., 2013). As leaf blades deplete with grazing, the animals will spend more time searching for green leaf blades within a canopy filled with stem and dead material, which results in a decrease in bite rate and intake rate (Fonseca et al., 2013). A better understanding of the forage harvesting process in the short-term may reveal opportunities for manipulation so as to achieve greater harvesting efficiency.

In mixed pastures of grass and legume, animal preferences also influence the forage harvest process
(Tsutsumi et al., 2016). Thus, the pre-grazing canopy height has an even more important effect on animal behavior because it affects not only the canopy structure, but also the botanical distribution between grass and legume. For instance, pastures of palisade grass and forage peanut managing pre-grazing canopies less than $25 \mathrm{~cm}$ in height have shown a greater proportion of legumes than pastures under $35 \mathrm{~cm}$ pre-grazing canopy height (Gomes et al., 2018). We hypothesized that animals grazing mixed canopies with greater pre-grazing heights would have their instantaneous intake rate reduced by an increased presence of stems. Additionally, more severe grazing intensity would also reduce the instantaneous intake rate due to a negative impact on bite mass and rate. Therefore, the objective of this study was to evaluate the effect of a different canopy structure, achieved by altering pre-grazing canopy heights and defoliation severity, on short-term ingestive behavior at a patch scale, in mixed grass-legume pastures.

\section{Materials and Methods}

\section{Experimental area}

The experiment was conducted at the research farm of the Federal University of Lavras, Brazil (21 ${ }^{\circ} 14^{\prime} 08.94^{\prime \prime}$ $\mathrm{S}, 44^{\circ} 58^{\prime} 06.96^{\prime \prime} \mathrm{W}$; altitude of $\left.923 \mathrm{~m}\right)$, during the rainy season (spring and summer) of 2016-2017. The experimental area consisted of mixed pastures of palisade grass and forage peanut. In Nov of 2016, the experimental area was standardized by mechanical cutting at $10 \mathrm{~cm}$ of stubble height and the forage 
removed from the experimental area. Subsequently, the experimental area was divided into 16 whole plots of 3.5 $\times 3.0 \mathrm{~m}$. Each whole plot was subsequently divided into three subplots of $3.5 \times 1.0 \mathrm{~m}$. Each subplot was further divided into three patches of $0.7 \times 0.7 \mathrm{~m}$, creating ninepatches per whole plot (Figure 1).

\section{Treatments and experimental design}

The experimental design was a completely randomized design with a split-plot arrangement $(2 \times 3)$. Two pre-grazing canopy heights $(\mathrm{CH})$ were studied in the whole plot: $25(\mathrm{CH} 25)$ or $35 \mathrm{~cm}(\mathrm{CH} 35)$. These pregrazing heights were chosen drawing on the results of Gomes et al. (2018), in which CH25 corresponded to light interception between 90 and $95 \%$, and CH35 corresponded to maximum light interception. This difference in canopy heights generated contrasting canopy structures. Three levels of defoliation severity (DS) corresponding to phases of the stocking period were investigated in the subplots: 1) no defoliation (DS0); 2) $20 \%$ depletion of pre-grazing canopy height (DS20); and 3) $40 \%$ depletion of pre-grazing canopy height (DS40).

\section{Preparation of patches}

When the whole plot reached the pre-grazing height, the subplots were randomized, followed by the preparation of grazing patches. In each subplot there were three patches, delineated with frames measuring $0.7 \times 0.7 \mathrm{~m}$. All biomass located outside the delineated areas was cut at ground level and removed from the subplots. After the patch preparation, all with similar canopy height within each whole plot, the defoliation severity was established.

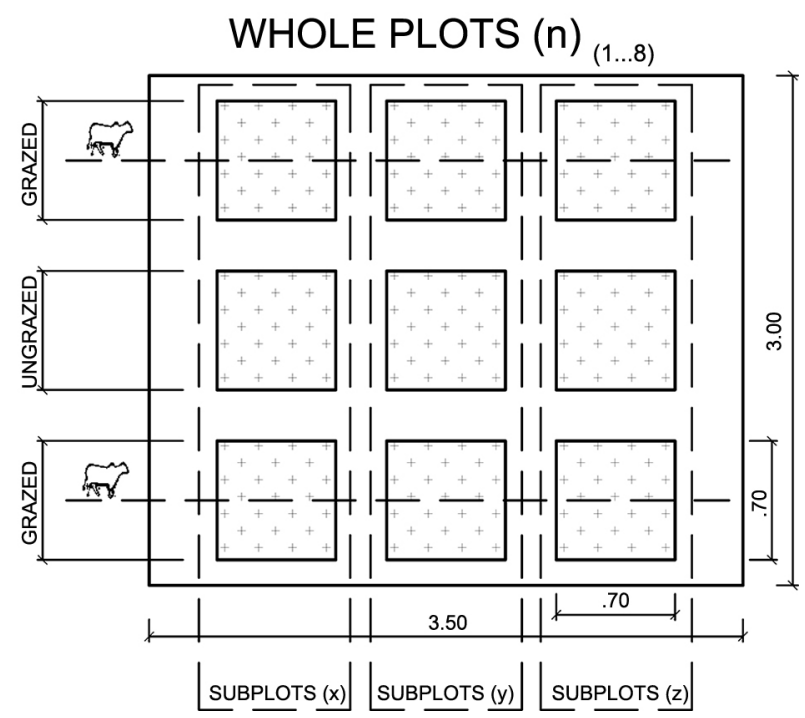

Figure 1 - Example of the method used to manage heifers in the experimental unit. The whole plot (canopy height) was divided into three subplots (levels of defoliation severity). $n=$ number of repetitions.
Thus, the forage of each patch was defoliated manually before the grazing (i.e., hand-plucking; Vries, 1995) to the desired canopy heights of DS20 and DS40 (Figure 1). After all the patch preparation, three corridors were created within each whole plot, using fences. In each corridor, there were three patches with different DS in random order. In two corridors grazing animals had unique access to each patch (Grazed; Figure 1). To facilitate an evaluation of the canopy structure before and after grazing and the forage removed by grazing animals in each treatment, there was no grazing in the third corridor (Ungrazed). The patch-grazing data were considered as the average of the two corridors where grazing occurred. After the preparation of all patches, the ingestive behavior was evaluated.

\section{Canopy structure measurements}

Both before and after grazing, the canopy heights were measured at eight points within each patch using the canopy surface height method (Braga et al., 2009). After grazing in two corridors, herbage mass was measured in all patches (grazed and ungrazed). In each patch, a frame was placed for canopy stratification. The upper stratum was the 0 to $20 \%$ forage of the initial canopy height. The second and third sward strata were between the layers of 20 to $40 \%$ and 40 to $60 \%$ of the initial canopy height, respectively. The fourth stratum was considered as forage less than $60 \%$ of the initial canopy height up to ground level (Fonseca et al., 2012). All the forage contained in each stratum was cut using the pruning shears. After harvesting the forage, botanical and morphological separations were performed. Grass samples were separated into stem (stem + sheath), leaf (leaf blade), and dead material. Legume samples were separated into stolon, leaf (stipule + petiole + leaflet), and dead material. Forage samples were oven-dried at $55^{\circ} \mathrm{C}$ for $72 \mathrm{~h}$ to constant weight. The forage mass / $\mathrm{g}$ $\mathrm{m}^{-2}$ ) of the botanical and morphological components was calculated for each stratum. Total herbage, grass, and legume masses were the sum of the masses in each stratum. The masses of patches that were not grazed were considered as the pre-grazing mass. The herbage, leaf, and stem bulk density above $40 \%$ sward strata were calculated by dividing the respective mass above $40 \%$ canopy strata $\left(\mathrm{g} \mathrm{m}^{-2}\right)$ by its height $(\mathrm{m})$.

\section{Ingestive behavior}

Two Bos indicus (Tabapuã) heifers with $450 \pm 13 \mathrm{~kg}$ of body weight were allowed to graze the patches (one in each corridor). The heifers had been previously conditioned to the experimental conditions, and trained for grazing in corridors. The animals were used as tools for forage harvesting. Heifers had no access to feed for $12 \mathrm{~h}$ before grazing. During the grazing of all patches, the animals were individually recorded using a digital video camera. 
All the videos of each animal were analyzed. In each patch, the total number of bites was measured. Grazing time in each patch was considered from the moment of the first bite in the patch until the animal moved to the next patch. A feeding station was defined as the patch area directly in front of and on each side of the animal when its front feet are stationary (Laca et al., 1992). The bite rate (bites $\mathrm{min}^{-1}$ ) was calculated by dividing the number of bites by the respective grazing time in each patch. The feeding-station per min (FS $\mathrm{min}^{-1}$ ) was calculated by dividing the number of feeding-stations by the time spent grazing. The number of bites per feeding-station was calculated by dividing the number of bites in each patch by the number of feeding-stations (Spalinger and Hobbs, 1992).

The ingested forage mass was calculated by the difference between forage mass in the ungrazed patch and the forage mass of the patch after grazing. The bite mass was calculated by dividing the ingested forage mass by the number of bites in each patch. The instantaneous intake rate was calculated by the ingested forage mass divided by the time spent by the animal in each patch (Benvenutti et al., 2006; Benvenutti et al., 2008). Bite mass, and instantaneous intake rate were not measured in the DS40 patches because the animals spent minimal time grazing this treatment.

\section{Statistical analysis}

Data were analyzed using the mixed model method (Littell et al., 2000), using the MIXED procedure of SAS (SAS Institute, version 9.0). The effects of pregrazing height, defoliation severity and their interaction were considered fixed. All variance components were estimated using the restricted maximum likelihood method. The treatment averages were estimated using the Least-Squares Means (LSMEANS) statement and compared using Fisher's protected least significant difference (LSD) with $p \leq 0.10$. The statistical model for data analysis was as follows:

$y_{i j}=\mu+C H_{i}+\varepsilon_{i}+D S_{j}+(C H * D S)_{i j}+\varepsilon_{i j}$

where $Y_{i j}=$ value observed in the ith $\mathrm{CH}$ of the jth $D S ; \mu=$ overall average; $C H_{i}=$ fixed effect associated with the ith pre-grazing heights, $i=1,2 ; \varepsilon_{i}=$ random error associated with the ith pre-grazing heights and repetitions; $D S_{j}=$ fixed effect associated with the jth levels of defoliation severity, $j=1,2,3 ; \varepsilon_{i}=$ random error associated with the ith pre-grazing heights, jth levels of defoliation severity and repetitions.

The fixed effect of strata was included in the statistical model to run canopy strata data. Strata interactions with other variables were also considered in the model. The ungrazed data were not evaluated statistically, since the data corresponding to the initial canopy condition were gathered before grazing.

\section{Results}

\section{Canopy structure}

The canopy structure data in the ungrazed and grazed patches are shown in Table 1. The canopy height in the ungrazed patches was established within the target height by hand-plucking. There was interaction between $\mathrm{CH}$ and DS at the canopy height of grazed patches $(p=$ 0.032 ). The canopy height in grazed patches was greater in $\mathrm{CH} 35$ than in $\mathrm{CH} 25$ in all DS. The percentage of the height removed by grazing was similar in the $\mathrm{CH} 25$ and CH35 patches (on average, $11.3 \%$ of the initial height). The canopy height in the grazed patches was greater in DSO and reduced with increasing DS. The percentages of the height removed by grazing were on average 18.9 , 9.6, and $2 \%$ of the initial height in the DSO, DS20, and DS40, respectively.

Total herbage mass, grass leaf mass, and legume leaf mass in the grazed patches were influenced by the interaction between $\mathrm{CH}$ and DS $(p=0.066, p=0.040$ and $p=0.066$, respectively). In DS0, total herbage, grass leaf, and legume leaf masses were greater in $\mathrm{CH} 35$ than $\mathrm{CH} 25$. However, there was no effect of $\mathrm{CH}$ on DS20 and DS40. In the CH25 target, total herbage and leaf legume masses in grazed patches were less in DS40 than in DSO and DS20. In CH35, total herbage and leaf legume masses decreased progressively in the greater DS. Grass leaf mass in the grazed patches decreased progressively in the greater DS in both $\mathrm{CH}$.

There was an interaction between $\mathrm{CH}$ and DS in the stem grass mass $(p=0.099)$. In all DS, greater stem mass was observed in $\mathrm{CH} 35$ than $\mathrm{CH} 25$. Post-grazing stem mass in $\mathrm{CH} 35$ was $156 \%, 102 \%$ and $80 \%$ in DS0, DS20 and DS40, respectively, then in CH25. In $\mathrm{CH} 25$, there was no difference in stem mass between the different DS treatments. In $\mathrm{CH} 35$, stem mass was higher in DS0 than in DS20 and DS40. Legume stem mass was influenced by both $\mathrm{CH}(p=0.002)$ and DS $(p$ $=0.026)$. The greatest stem legume mass was observed in CH35, while DS0 and DS20 were greater than DS40. The botanical composition (proportion of legume in the canopy) was not influenced by either $\mathrm{CH}$ and or DS ( $p=0.633$ and $p=0.372$, respectively). The mean botanical composition was $57 \%$ of forage peanut on herbage mass.

Herbage bulk density above $40 \%$ sward strata was influenced by $\mathrm{CH}(p=0.063)$ and DS $(p=0.018)$. The greatest herbage bulk density above $40 \%$ sward strata was found for $\mathrm{CH} 35$ and DSO. There was no $\mathrm{CH}$ effect ( $p=0.867$ ) on leaf herbage bulk density above the $40 \%$ sward strata. However, the highest value of leaf herbage bulk density above $40 \%$ sward strata was found for DSO $(p=0.001)$. The highest stem herbage bulk density above $40 \%$ sward strata was observed in CH35 ( $p<0.001)$. No differences were found in stem herbage bulk density above the $40 \%$ sward strata for DS ( $p=0.944)$. 
Table 1 - Canopy characteristics of palisade grass and forage peanut subjected to different defoliation frequency and severity.

\begin{tabular}{|c|c|c|c|c|c|c|c|c|c|c|c|c|}
\hline \multirow{2}{*}{ Item } & \multicolumn{4}{|c|}{$\mathrm{CH} 25 \mathrm{~cm}$} & \multicolumn{4}{|c|}{$\mathrm{CH} 35 \mathrm{~cm}$} & \multirow{2}{*}{$\mathrm{SEM}^{1}$} & \multicolumn{3}{|c|}{$p$-value } \\
\hline & $0 \%$ & $20 \%$ & $40 \%$ & Mean & $0 \%$ & $20 \%$ & $40 \%$ & Mean & & $\mathrm{CH}$ & DS & $\mathrm{CH} \times \mathrm{DS}$ \\
\hline & \multicolumn{12}{|c|}{ Height (cm) } \\
\hline Ungrazed & 23.3 & 19.6 & 15.7 & 19.5 & 37.5 & 29.9 & 23.9 & 30.4 & 1.1 & - & - & - \\
\hline \multirow[t]{2}{*}{ Grazed } & 19.2 Ba & $17.8 \mathrm{Bb}$ & $15.4 \mathrm{Bc}$ & 15.5 & $29.9 \mathrm{Aa}$ & $26.9 \mathrm{Ab}$ & $23.4 \mathrm{Ac}$ & 26.7 & 0.7 & $<0.001$ & $<0.001$ & 0.032 \\
\hline & \multicolumn{12}{|c|}{ Total herbage mass ( $\mathrm{g} \mathrm{m}^{-2}$ ) } \\
\hline Ungrazed & 725 & 635 & 463 & 608 & 839 & 617 & 492 & 649 & 26 & - & - & - \\
\hline \multirow[t]{2}{*}{ Grazed } & $579 \mathrm{Ba}$ & $553 \mathrm{Aa}$ & $443 \mathrm{Ab}$ & 525 & $707 \mathrm{~A} \mathrm{a}$ & $577 \mathrm{Ab}$ & $466 \mathrm{Ac}$ & 583 & 29 & 0.071 & $<0.001$ & 0.066 \\
\hline & \multicolumn{12}{|c|}{ Botanical composition (\% of legume mass) } \\
\hline Ungrazed & 58.8 & 65.2 & 53.6 & 59.2 & 53.8 & 56.6 & 52.9 & 54.4 & 0.04 & - & - & - \\
\hline \multirow[t]{2}{*}{ Grazed } & 56.9 & 61.2 & 55.9 & 58.0 & 52.5 & 58.1 & 57.3 & 56.0 & 0.04 & 0.633 & 0.372 & 0.675 \\
\hline & \multicolumn{12}{|c|}{ Grass leaf mass ( $\mathrm{g} \mathrm{m}^{-2}$ ) } \\
\hline Ungrazed & 85 & 44 & 26 & 52 & 136 & 49 & 33 & 73 & 8.7 & - & - & - \\
\hline \multirow[t]{2}{*}{ Grazed } & $56 \mathrm{Ba}$ & $41 \mathrm{Ab}$ & $29 \mathrm{Ac}$ & 42 & $71 \mathrm{Aa}$ & $43 \mathrm{Ab}$ & $20 \mathrm{Ac}$ & 45 & 6.3 & 0.745 & $<0.001$ & 0.040 \\
\hline & \multicolumn{12}{|c|}{ Grass stem mass $\left(\mathrm{g} \mathrm{m}^{-2}\right)$} \\
\hline Ungrazed & 44 & 32 & 42 & 39 & 115 & 82 & 70 & 89 & 8.1 & - & - & - \\
\hline \multirow[t]{2}{*}{ Grazed } & $39 \mathrm{Ba}$ & $37 \mathrm{Ba}$ & $35 \mathrm{Ba}$ & 37 & $100 \mathrm{Aa}$ & $75 \mathrm{Ab}$ & $63 \mathrm{Ab}$ & 79 & 9.3 & 0.001 & 0.030 & 0.099 \\
\hline & \multicolumn{12}{|c|}{ Legume leaf mass $\left(\mathrm{g} \mathrm{m}^{-2}\right)$} \\
\hline Ungrazed & 149 & 106 & 35 & 97 & 141 & 81 & 33 & 85 & 7.9 & - & - & - \\
\hline \multirow[t]{2}{*}{ Grazed } & $70 \mathrm{Ba}$ & $66 \mathrm{Aa}$ & $36 \mathrm{Ab}$ & 57 & $92 \mathrm{Aa}$ & $63 \mathrm{Ab}$ & $38 \mathrm{Ac}$ & 64 & 6.5 & 0.279 & $<0.001$ & 0.066 \\
\hline & \multicolumn{12}{|c|}{ Legume stem mass $\left(\mathrm{g} \mathrm{m}^{-2}\right)$} \\
\hline Ungrazed & 178 & 208 & 134 & 173 & 255 & 220 & 179 & 218 & 15 & - & - & - \\
\hline \multirow[t]{2}{*}{ Grazed } & 169 a & $176 \mathrm{a}$ & $136 \mathrm{~b}$ & $160 \mathrm{~B}$ & 228 a & 218 a & $192 \mathrm{~b}$ & $213 \mathrm{~A}$ & 15 & 0.002 & 0.026 & 0.803 \\
\hline & \multicolumn{12}{|c|}{ Herbage bulk density above $40 \%$ sward strata $\left(\mathrm{mg} \mathrm{cm}^{-3}\right)$} \\
\hline Ungrazed & 2.1 & 1.6 & - & 1.8 & 2.3 & 1.1 & - & 1.7 & 0.1 & - & - & - \\
\hline \multirow[t]{2}{*}{ Grazed } & $1.0 \mathrm{a}$ & $0.9 \mathrm{~b}$ & - & $0.9 \mathrm{~B}$ & $1.4 \mathrm{a}$ & $1.0 \mathrm{~b}$ & - & $1.2 \mathrm{~A}$ & 0.1 & 0.063 & 0.018 & 0.131 \\
\hline & \multicolumn{12}{|c|}{ Leaf herbage bulk density above $40 \%$ sward strata $\left(\mathrm{mg} \mathrm{cm}^{-3}\right)$} \\
\hline Ungrazed & 1.7 & 1.0 & - & 1.3 & 1.4 & 0.5 & - & 0.9 & 0.1 & - & - & - \\
\hline \multirow[t]{2}{*}{ Grazed } & $0.6 \mathrm{a}$ & $0.5 \mathrm{~b}$ & - & 0.5 & $0.6 \mathrm{a}$ & $0.4 \mathrm{~b}$ & - & 0.5 & 0.05 & 0.867 & 0.001 & 0.239 \\
\hline & \multicolumn{12}{|c|}{ Stem herbage bulk density above $40 \%$ sward strata $\left(\mathrm{mg} \mathrm{cm}^{-3}\right)$} \\
\hline Ungrazed & 0.3 & 0.5 & - & 0.4 & 0.6 & 0.5 & - & 0.5 & 0.03 & - & - & - \\
\hline Grazed & 0.3 & 0.3 & - & $0.3 \mathrm{~B}$ & 0.5 & 0.5 & - & $0.5 \mathrm{~A}$ & 0.04 & $<0.001$ & 0.944 & 0.427 \\
\hline
\end{tabular}

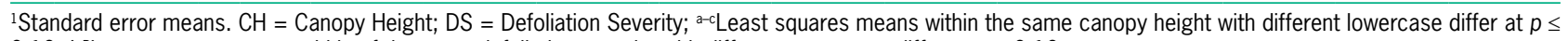
$0.10 ;{ }^{A-B}$ Least squares means within of the same defoliation severity with different uppercase differ at $p \leq 0.10$.

\section{Canopy stratification}

Total herbage mass, grass mass, and legume mass per stratum of the ungrazed and grazed canopies in $\mathrm{CH} 25$ are shown in Figures 2A, B, C, 3A, B, C, and 4A, B, C. In DS0, total herbage mass and legume mass were higher in the ungrazed patch than in the grazed one, in the $0-20,20-40$ and $40-60 \%$ of the sward strata. The grass mass was lower in grazed patches than in ungrazed ones in the $0-20$ and $20-40 \%$ of the sward strata. For DS20, total herbage mass and legume mass decreased in the $20-40$ and $40-60 \%$ of the sward strata in the grazed plot. Grass mass was no different in either grazed or ungrazed patches of DS20. In DS40, no difference was observed in total herbage, grass, and legume masses ( $p$ $=0.678, p=0.562$ and $p=0.789$, respectively) between grazed and ungrazed patches.

Total herbage mass, grass mass, and legume mass per stratum of the ungrazed and grazed canopies in CH35 are shown in Figure 2D, E, F, 3D, E, F, and 4D, $\mathrm{E}, \mathrm{F}$. In the DS0, total herbage mass, grass mass, and legume mass decreased in grazed patches relative to ungrazed ones in the $0-20$ and $20-40 \%$ of the sward strata. In DS20, the total forage mass and grass mass were lower in the grazed patches than in the ungrazed ones in $20-40 \%$ of the sward stratum. Legume mass was no different in either grazed or ungrazed patches of DS20 ( $p=0.213)$. In the DS40, there was no difference in total herbage, grass, and legume masses $(p=0.843, p$ $=0.723$ and $p=0.298$, respectively) in either grazed or ungrazed patches.

\section{Short-term ingestive behavior}

Data on short-term ingestive behavior are presented in Table 2. The total number of bites was not influenced by $\mathrm{CH}(p=0.519)$, with an average of 44 bites patch $^{-1}$. In both $\mathrm{CH}$ treatments, the total number of bites was progressively reduced in line with increases in defoliation severity $(p<0.001)$. Interaction of $\mathrm{CH}$ and DS in time grazing in each patch ( $p=0.001)$ was verified. In DSO, total grazing time was longer in $\mathrm{CH} 35$ 
Table 2 - Ingestive behavior of heifers in palisade grass and forage peanut canopy subjected to different defoliation frequency and severity.

\begin{tabular}{|c|c|c|c|c|c|c|c|c|c|c|c|c|}
\hline \multirow{2}{*}{ Variables } & \multicolumn{4}{|c|}{$25 \mathrm{~cm}$} & \multicolumn{4}{|c|}{$35 \mathrm{~cm}$} & \multirow{2}{*}{ SEM $^{1}$} & \multicolumn{3}{|c|}{$p$-value } \\
\hline & $0 \%$ & $20 \%$ & $40 \%$ & Mean & $0 \%$ & $20 \%$ & $40 \%$ & Mean & & $\mathrm{CH}$ & DS & $\mathrm{CH} \times \mathrm{DS}$ \\
\hline Total bites per patch & $79.5 \mathrm{a}$ & $45.4 \mathrm{~b}$ & $12.7 \mathrm{c}$ & 45.9 & $83.1 \mathrm{a}$ & $34.8 b$ & $6.7 \mathrm{c}$ & 41.5 & 7.1 & 0.519 & $<0.001$ & 0.417 \\
\hline Total grazing time (s) & $98.3 \mathrm{Ba}$ & $60.8 \mathrm{Ab}$ & 16.4 Ac & 58.5 & 147.2 Aa & $62.9 \mathrm{Ab}$ & $15.6 \mathrm{Ac}$ & 75.2 & 8.6 & 0.059 & $<0.001$ & 0.001 \\
\hline Number of feed station & $6.8 \mathrm{a}$ & $6.5 b$ & $4.1 \mathrm{c}$ & $5.8 \mathrm{~A}$ & $6.1 \mathrm{a}$ & $4.6 \mathrm{~b}$ & $2.2 \mathrm{c}$ & $4.3 \mathrm{E}$ & 0.6 & 0.006 & $<0.001$ & 0.429 \\
\hline Bite rate (bites $\mathrm{min}^{-1}$ ) & $48.2 \mathrm{a}$ & $46.8 \mathrm{a}$ & $45.7 b$ & $46.9 \mathrm{~A}$ & $33.8 \mathrm{a}$ & $31.7 \mathrm{a}$ & $24.2 b$ & $29.9 B$ & 2.3 & 0.001 & 0.026 & 0.199 \\
\hline Feed station per min & $4.3 c$ & $7.4 \mathrm{~b}$ & $15.6 \mathrm{a}$ & $9.1 \mathrm{~A}$ & $2.5 \mathrm{c}$ & $4.6 \mathrm{~b}$ & $9.5 \mathrm{a}$ & $5.5 \mathrm{~B}$ & 1.2 & 0.020 & $<0.001$ & 0.115 \\
\hline Bites/Feed station & $11.7 \mathrm{Ba}$ & 7.1 Ab & $3.4 \mathrm{Ac}$ & 7.4 & 13.9 Аа & 7.3 Ab & $2.8 \mathrm{Ac}$ & 8.0 & 0.8 & 0.473 & $<0.001$ & 0.081 \\
\hline Bite mass (mg kg-1 BW) & $2.0 \mathrm{a}$ & $1.6 \mathrm{~b}$ & - & $1.8 \mathrm{~A}$ & $1.5 \mathrm{a}$ & $0.9 \mathrm{~b}$ & - & $1.2 \mathrm{~B}$ & 0.1 & 0.068 & 0.032 & 0.818 \\
\hline Instantaneous intake rate $\left(\mathrm{g} \mathrm{min}^{-1}\right)$ & $45.5 \mathrm{a}$ & $37.2 \mathrm{~b}$ & - & $41.3 \mathrm{~A}$ & $24.5 \mathrm{a}$ & $11.8 \mathrm{~b}$ & - & $18.1 \mathrm{~B}$ & 5.6 & 0.074 & 0.016 & 0.793 \\
\hline
\end{tabular}

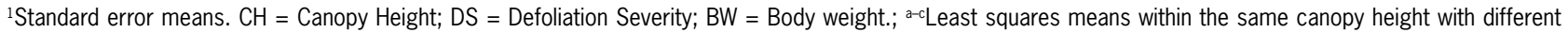
lowercase differ at $p \leq 0.10$; ${ }^{A-B}$ Least squares means within of the same defoliation severity with different uppercase differ at $p \leq 0.10$.
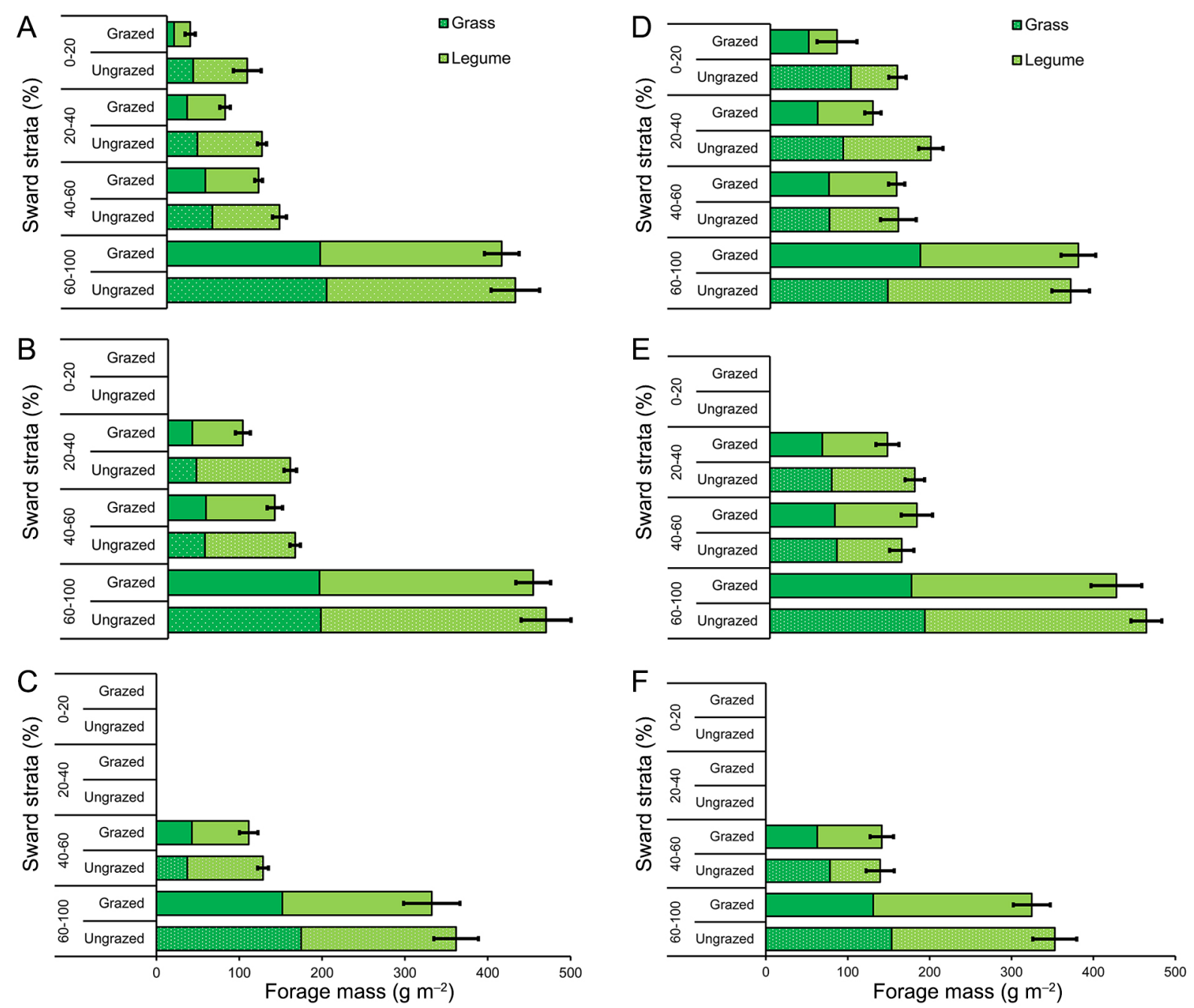

Figure 2 - Proportion of grass and legume mass per strata in canopy height of $25 \mathrm{~cm}$ (left) and $35 \mathrm{~cm}$ (right) and different defoliation severities ( $\mathrm{A}$ and $\mathrm{D}=\mathrm{DSO}$; $\mathrm{B}$ and $\mathrm{E}=\mathrm{DS} 20$; and $\mathrm{C}$ and F = DS40). DS0 = no defoliation; DS20 = depletion $20 \%$ of pre-grazing canopy height; DS40 = depletion $40 \%$ of pre-grazing canopy height. Error bars represent standard error means.

than in $\mathrm{CH} 25$. In the other DS treatments, there was no difference between $\mathrm{CH} 35$ and $\mathrm{CH} 25$. In both $\mathrm{CH}$ treatments, total grazing time was longer in DSO and progressively reduced in line with increases in DS. The number of feeding stations was longer in $\mathrm{CH} 25$ than CH35 ( $p=0.006)$. The total feeding station time was longer in DS0 and progressively reduced with increases in DS $(p<0.001)$. 
Bite rate and feeding station per min were influenced by $\mathrm{CH}(p<0.001$ and $p=0.020$, respectively) and DS ( $p=0.026$ and $p<0.001$, respectively). The maximum bite rate was observed for $\mathrm{CH} 25$ (56.8 \% more bites than $\mathrm{CH} 35)$. The same bite rate behavior in the $\mathrm{CH}$ was observed in feeding stations per min. As regards DS, there was no difference in $\mathrm{CH} 25$ in bite rate. In $\mathrm{CH} 35$, the bite rate was the same for DSO and DS20, but both differed from DS40. In the CH25, all DS were different, and DS40 presented the highest feeding station per min. The same was observed for $\mathrm{CH} 35$, where DS40 obtained the highest feeding station per min.

There was interaction between $\mathrm{CH}$ and DS $(p=$ 0.081) for bites/feeding station. Between $\mathrm{CH}$, there was only a difference in DSO, in which $\mathrm{CH} 35$ was $18.8 \%$ greater than $\mathrm{CH} 25$. As regards DS, the same behavior was observed in bites/feeding stations in both $\mathrm{CHs}$, where all were different and the highest value found in DS0. For the bite mass and instantaneous intake rate, there were effects of $\mathrm{CH}(p=0.068$ and $p=0.074$, respectively) and DS ( $p=0.032$ and $p=0.016$, respectively), with no interaction. For $\mathrm{CH}$, greater bite mass and instantaneous intake rate were obtained in the $\mathrm{CH} 25$ (increases of $50 \%$ and $128 \%$, respectively). As regards DS, lower bite mass and instantaneous intake rate were found for DS20 compared to DS0 (reduction of $20 \%$ in CH25 and $40 \%$ in $\mathrm{CH} 35$ for bite mass, respectively; and decreases of $18 \%$ in $\mathrm{CH} 25$ and $52 \%$ in $\mathrm{CH} 35$ for instantaneous intake rates, respectively).

\section{Discussion}

Grazing management controlling the regrowth of tropical grass affects the canopy structure, influencing plant, and consequently, animal responses. In the regrowth period, when light is limited in the lower canopy stratum (i.e., light interception above $95 \%$ ), tropical grasses increase stem elongation rather than leaf elongation (Carnevalli et al., 2006; Silveira et al., 2016). In mixed palisade grass-forage peanut canopies, pregrazing canopy height ranged from 24 to $30 \mathrm{~cm}$ results in low competition for light between plants (Gomes et al., 2018) which is accentuated/maximized in pregrazing canopy heights in excess of $35 \mathrm{~cm}$ (Gomes et al., 2018). Thus, in the present study, the total herbage mass of $\mathrm{CH} 35$ and no defoliation (DSO) was higher (15.7\%) than in $\mathrm{CH} 25$. This increase in herbage mass was due to increased stem grass mass, which was $161 \%$ greater in CH35 than CH25 (Table 1). Moreover, the increase in grass stem mass contributed to promote stem elongation up to the top of the canopy $(0-20 \%$ sward stratum, Figure 3D and 4D). In CH35 without defoliation, $20.1 \%$ of the stem mass was located in the canopy top strata. In $\mathrm{CH} 25$, only $1 \%$ of the stem mass was located in the canopy top layer. Furthermore, $\mathrm{CH} 35$ had an increase of $50 \%$ in the stem herbage bulk density above the $40 \%$ sward strata.
Canopy structure modifies livestock short-term ingestion capacity (Carvalho et al., 2015; Guzatti et al., 2017). The highest instantaneous intake rate in $\mathrm{CH} 25 /$ DSO was due to the increased bite mass associated with a faster bite rate, which can be explained by the ease of selection, apprehension, and forage intake since the upper canopy stratum was characterized by a predominance of leaves. Thus, the bite removed leaf up to the $20-40 \%$ sward stratum. This is due to a deep bite of the high leaf bulk density in that stratum (Table 1).

In $\mathrm{CH} 35 / \mathrm{DSO}$, the instantaneous intake rate was lower than in $\mathrm{CH} 25$ because of the lower bite mass and rate. The bite mass was lower due to decreases in the leaf bulk density in the grazed strata, and possibly, to the animal ingesting a smaller volume with each bite. The bite volume is defined by the bite depth and bite area (Stobbs, 1973). We can infer that in CH35/DS0 the bite depth (the difference between canopy height of the ungrazed and grazed patches) was greater than in $\mathrm{CH} 25 /$ DS0. However, the percentage removed from the height in the DSO in both $\mathrm{CH}$ was $20 \%$ relative to the height of the ungrazed patches. Thus, the length removed in $\mathrm{CH} 35$ exceeded that in $\mathrm{CH} 25(7.6$ vs. $4.1 \mathrm{~cm}$, respectively; Table 1), and the smaller bite volume probably resulted from a reduction in the bite area which is related to the pasture structure (Benvenutti et al., 2006; Drescher et al., 2006). In pastures with predominant upper strata of leaves, the bite area is maximized due to the benefits of tongue movement to grasp forage (Benvenutti et al., 2006; Benvenutti et al., 2008). In canopies with greater presence of stem at the top strata, the bite area is limited, since the shearing force of the stem is elevated (Barrett et al., 2001; Baumont et al., 2004; Gregorini et al., 2011). Thus, the stems act as a barrier interfering with the tongue movements leading the cattle to exclude the stems from the bite by reducing the reach of the tongue sweeps (Benvenutti et al., 2006). Grazing animals in patches CH35/DS0 had significantly more bites in each feeding station and remained longer at each feeding station than with the combination of CH25/DS0 (Table 2). This is indicative of a likely reduction in bite area in this treatment combination. A greater presence of stem in the top canopy layer not only reduces bite area but also causes the animal to spend more time in the selection and apprehension of the leaf (Benvenutti et al., 2006). This may explain the lower bite rate in CH35/DS0 than in CH25/DS0. Thus, our data support the hypothesis that animals grazing mixed canopies with greater pre-grazing heights have their instantaneous intake rate reduced by a greater presence of stems.

There was a presence of legumes at the top of the canopy in both $\mathrm{CHs}$, even at the $37.5 \mathrm{~cm}$ canopy height. In taller canopies, forage peanut grows up in a vertical direction as a light competition strategy (Pereira et al., 2017; Tamele et al., 2018). In canopies where light interception does not exceed $95 \%$, only leaves of the forage peanut are located at the top of the canopy. On the other hand, when the canopy height exceeds $30 \mathrm{~cm}$, there 

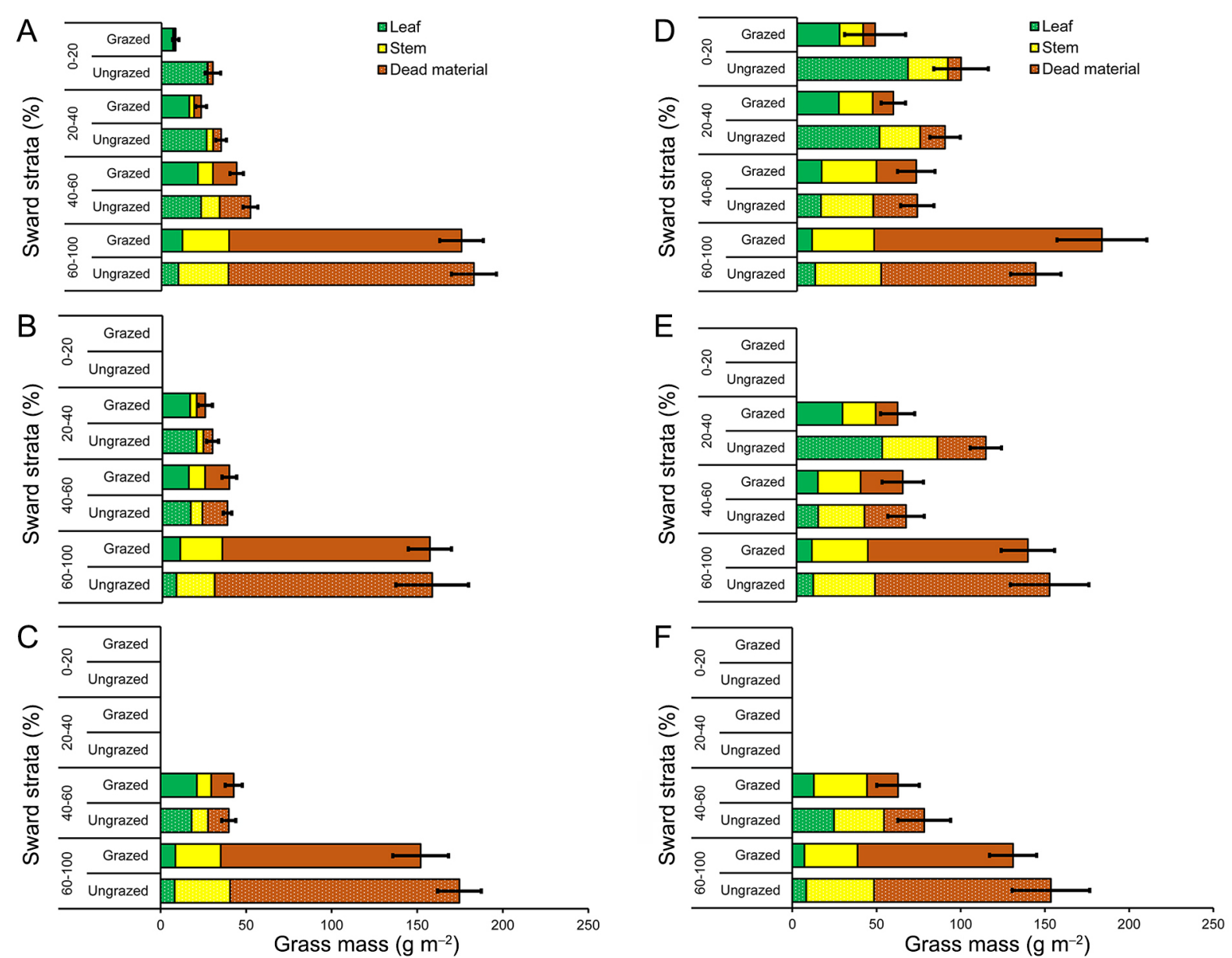

Figure 3 - Proportion of morphological components of grass mass per strata in canopy height of $25 \mathrm{~cm}$ (left) and $35 \mathrm{~cm}$ (right) and different defoliation severities ( $A$ and $D=D S 0 ; B$ and $E=D S 20 ;$ and $C$ and F = DS40). DS0 = no defoliation; DS20 = depletion $20 \%$ of pre-grazing canopy height; DS40 = depletion $40 \%$ of pre-grazing canopy height. Error bars represent standard error means.

is a more significant proportion of forage peanut stolon in the top canopy strata (Gomes et al., 2018). This pattern of response was observed in the present study (Figure $4 \mathrm{D}$ and $\mathrm{E}$ ). The vertical stolon elongation of the forage peanut observed in $\mathrm{CH} 35$ leaves the apical meristems more exposed to grazing. This is a possible explanation of a three-fold greater disappearance of legume stem in CH35/DS0 than in CH25/DS0 (9 vs. $27 \mathrm{~g} \mathrm{~m}^{-2}$; Table 1). Greater decapitation of forage peanut stolon may impact plant response on subsequent regrowth, which, in turn, compromises legume stability in the canopy (Black et al., 2009; Gomes et al., 2018).

The reduction in canopy height after grazing using DS0 in both $\mathrm{CH}$ was approximately $20 \%$, similar to that performed manually in DS20 (Table 1). Thus, the short-term ingestive behavior responses in DS20 were equivalent to second-layer grazing during the lowering process. In $\mathrm{CH} 35$ with no defoliation, approximately $50 \%$ of the leaves were located in the $0-20 \%$ stratum of the canopy height. In $\mathrm{CH} 25$ without defoliation, only approximately $30 \%$ of the leaves were located in the same stratum. Thus, proportionally, leaf depletion in DS20 was greater in $\mathrm{CH} 35$ than in $\mathrm{CH} 25$. This response, associated with greater stem proportion at the top of the CH35 canopy, increased the difference in the canopy structure compared to $\mathrm{CH} 25$ in the DS20. This difference was reflected in the instantaneous intake rate, which was more than three times greater in the CH25/DS20 than $\mathrm{CH} 35 / \mathrm{DS} 20$. The reduction in the instantaneous intake rate in DS20 compared to DSO was due to the lower bite mass since the bite rates were similar (Table 2). The bite mass was reduced mainly due to a lower bite depth; the canopy height was reduced by $9.2 \%(1.8 \mathrm{~cm})$ and $10 \%(3.0 \mathrm{~cm})$ in the CH25/DS20 and CH35/DS20, respectively, compared to the ungrazed patches (Table 1). The reduction in bite mass in CH35/DS20 compared to $\mathrm{CH} 35 / \mathrm{DS} 0$ was more pronounced than that observed in $\mathrm{CH} 25 / \mathrm{DS} 20$. The bite mass and bite rate were lower than in CH35/DS20 than the observed CH25/DS20 (Table 2). This fact is linked to a greater stem proportion in the 20$40 \%$ stratum in CH35/DS20 than in CH25/DS20 (12.1 vs. $33.8 \%$, respectively) and lower leaf herbage bulk density 

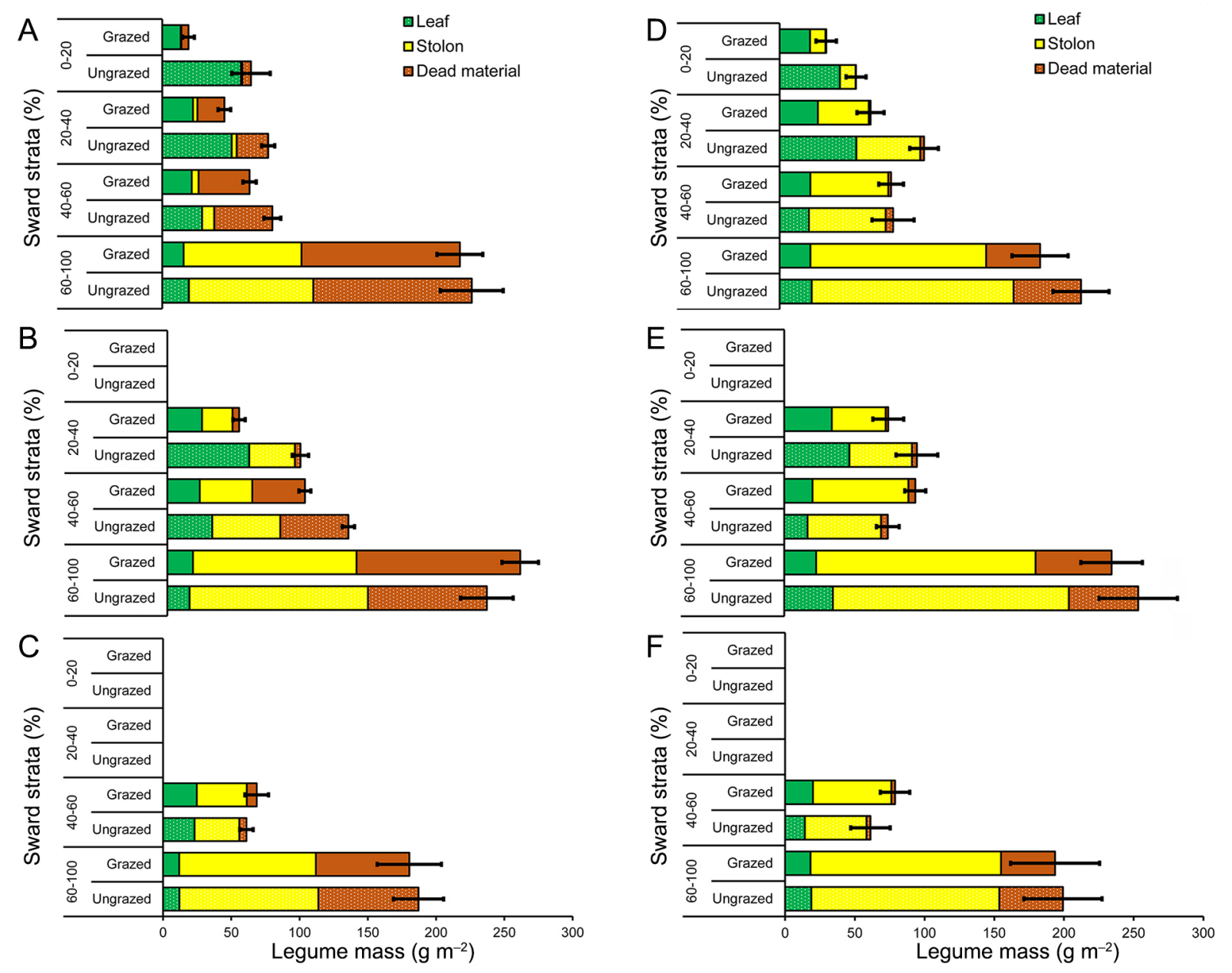

Figure 4 - Proportion of morphological components of legume mass per strata in canopy height of $25 \mathrm{~cm}$ (left) and $35 \mathrm{~cm}$ (right) and different defoliation severities ( $\mathrm{A}$ and $\mathrm{D}=\mathrm{DSO} ; \mathrm{B}$ and $\mathrm{E}=\mathrm{DS} 20$; and $\mathrm{C}$ and $\mathrm{F}=\mathrm{DS} 40$ ). DS0 $=$ no defoliation; $\mathrm{DS} 20=$ depletion $20 \%$ of pre-grazing canopy height; DS40 = depletion $40 \%$ of pre-grazing canopy height. Error bars represent standard error means.

(Table 1). Therefore, the pre-grazing height of $35 \mathrm{~cm}$ should not be used. However, in the case of a pre-grazing canopy height above $25 \mathrm{~cm}$, the increase in defoliation severity causes negative impacts on the instantaneous intake rate.

Therefore, the time spent in each feeding station and the number of bites in each feeding station decreased as the defoliation became more severe, indicating that the animal was going through the patches faster as a grazing strategy. In DS40 patches, this strategy became so evident that the low number of bites in each patch resulted in difficulty in estimating bite mass and instantaneous intake rate. This behavior explains the linear decrease in intake rates observed by Fonseca et al. (2012) when the animals grazed more than $40 \%$ of pre-grazing canopy height. This linear decrease is linked to the large-scale increase in the stem proportion in the available grazed stratum (Figure $3 \mathrm{C}-\mathrm{F}$ and $4 \mathrm{C}-\mathrm{F}$ ). Consequently, the number of mandibular movements per unit of ingested dry matter increased linearly beyond the $40 \%$ reduction of pre-grazing height
(Fonseca et al., 2012). Additionally, in the DS40 patches in both $\mathrm{CH}$ treatments, there was a greater number of feeding stations per min and a lower number of bites per feeding station both of which characterize a search by the animal for a patch with a better canopy structure. In rotational stocking with defoliation severity near 40 $\%$, animals stopped grazing when the sward structure became a limiting factor (e.g., the proportion of leaves at the end of the grazing period; Amaral et al., 2013). This effect has been described by Ribeiro Filho et al. (2003) as a change in the disposition of the animal waiting to enter a new plot, which leads to reduced total herbage intake. Thus, our data support the hypothesis that more severe grazing intensity reduces the instantaneous intake rate due to a negative impact on bite mass and rate.

\section{Conclusion}

The canopy structure in terms of the leaf and stem presence in the upper stratum is the main factor which 
influences the ingestive behavior characteristics in the short-term. Thus, greater stem mass in the grazing strata negatively influenced the instantaneous intake rate. Under rotational stocking, a pre-grazing canopy height of $25 \mathrm{~cm}$ should be used in mixed pastures of palisade grass and forage peanut. Instantaneous intake rate has a proportionately inverse relationship with defoliation severity.

\section{Acknowledgments}

This work was funded by the Minas Gerais Research Foundation (FAPEMIG), National Council for Scientific and Technological Development (CNPq), National Institute of Science and Technology in Animal Science (INCT-CA) and Coordination for the Improvement of Higher Education Personnel (CAPES). The authors thank the members of NEFOR (Brazilian Forage Team) for their contributions during the field trial setup.

\section{Authors' Contributions}

Conceptualization: Ferreira, I.M.; Homem, B.G.C.; Lima, I.B.G. Data acquisition: Ferreira, I.M.; Homem, B.G.C.; Lima, I.B.G. Data analysis: Ferreira, I.M.; Homem, B.G.C.; Casagrande, D.R. Design of methodology: Homem, B.G.C.; Bernardes, T.F.; Casagrande, D.R. Writing and editing: Homem, B.G.C.; Dubeux Junior, J.C.B.; Bernardes, T.F.; Danés, M.A.C; Casagrande, D.R.

\section{References}

Amaral, M.F.; Mezzalira, J.C.; Bremm, C.; Trindade, J.K.; Gibb, M.J.; Suñe, R.W.M.; Carvalho, P.C.F. 2013. Sward structure management for a maximum short-term intake rate in annual ryegrass. Grass and Forage Science 68: 271-277.

Barrett, P.D.; Laidlaw, A.S.; Mayne, C.S.; Christie, H. 2001. Pattern of herbage intake rate and bite dimensions of rotationally grazed dairy cows as sward height declines. Grass and Forage Science 56: 362-373.

Baumont, R.; Cohen-Salmon, D.; Prache, S.; Sauvant, D. 2004. A mechanistic model of intake and grazing behavior in sheep integrating sward architecture and animal decisions. Animal Feed Science and Technology 112: 5-28.

Benvenutti, M.A.; Gordon, I.J.; Poppi, D.P. 2006. The effect of the density and physical properties of grass stems on the foraging behavior and instantaneous intake rate by cattle grazing an artificial reproductive tropical sward. Grass and Forage Science 61: 272-281.

Benvenutti, M.A.; Gordon, I.J.; Poppi, D.P. 2008. The effects of stem density of tropical swards and age of grazing cattle on their foraging behavior. Grass and Forage Science 63: 1-8.

Benvenutti, M.A.; Pavetti, D.R.; Poppi, D.P.; Gordon, I.J.; Cangiano, C.A. 2016. Defoliation patterns and their implications for the management of vegetative tropical pastures to control intake and diet quality by cattle. Grass and Forage Science 71: 424-436.
Black, A.D.; Laidlaw, A.S.; Moot, D.J.; O'Kiely, P. 2009. Comparative growth and management of white and red clovers. Irish Journal of Agricultural and Food Research 48: 149-166.

Braga, G.J.; Pedreira, C.G.S.; Herling, V.R.; Luz, P.H.C.; Marchesin, W.A.; Macedo, F.B. 2009. Quantifying herbage mass on rotationally stocked palisade grass pastures using indirect methods. Scientia Agricola 66: 127-131.

Carnevalli, R.A.; Silva, S.C.; Bueno, A.A.O.; Uebele, M.C.; Bueno, F.O.; Hodgson, J.; Silva, G.N.; Morais, J.P.G. 2006. Herbage production and grazing losses in Panicum maximum cv. Mombaca under four grazing managements. Tropical Grasslands 40: 165-176.

Carvalho, P.C.F.; Bremm, C.; Mezzalira, J.C.; Fonseca, L.; Trindade, J.K.; Bonnet, O.J.F.; Tischler, M.; Genro, T.C.M.; Nabinger, C.; Laca, E.A. 2015. Can animal performance be predicted from short-term grazing processes? Animal Production Science 55: 319-327.

Drescher, M.; Heitkönig, I.M.A.; Raats, J.G.; Prins, H.H.T. 2006. The role of grass stems as structural foraging deterrents and their effects on the foraging behaviour of cattle. Applied Animal Behaviour Science 101: 10-26.

Fonseca, L.; Mezzalira, J.C.; Bremm, C.; Filho, R.S.A.; Gonda, H.L.; Carvalho, P.C.F. 2012. Management targets for maximizing the short-term herbage intake rate of cattle grazing in Sorghum bicolor. Livestock Science 145: 205-211.

Fonseca, L.; Carvalho, P.C.F.; Mezzalira, J.C.; Bremm, C.; Galli, J.R.; Gregorini, P. 2013. Effect of sward surface height and level of herbage depletion on bite features of cattle grazing Sorghum bicolor swards. Journal of Animal Science 91: 43574365.

Gomes, F.K.; Oliveira, M.D.B.L.; Homem, B.G.C.; Boddey, R.M.; Bernardes, T.F.; Gionbelli, M.P.; Lara, M.A.S.; Casagrande, D.R. 2018. Effects of grazing management in brachiaria grassforage peanut pastures on canopy structure and forage intake. Journal of Animal Science 96: 3837-3849.

Gregorini, P.; Gunter, S.A.; Bowman, M.T.; Caldwell, J.D.; Masino, C.A.; Coblentz, W.K.; Beck, P.A. 2011. Effect of herbage depletion on short-term foraging dynamics and diet quality of steers grazing wheat pastures. Journal of Animal Science 89: 3824-3830.

Guzatti, G.C.; Duchini, P.G.; Sbrissia, A.F.; Mezzalira, J.C.; Almeida, J.G.R.; Carvalho, P.C.F.; Ribeiro-Filho, H.M.N. 2017. Changes in the short-term intake rate of herbage by heifers grazing annual grasses throughout the growing season. Grassland Science 63: 255-264.

Laca, E.A.; Ungar, E.D.; Seligman, N.G.; Ramey, M.R.; Demment, M.W. 1992. An integrated methodology for studying short term grazing behaviour of cattle. Grass and Forage Science 47: 81-90.

Littell, R.C.; Pendergast, J.; Natarajan, R. 2000. Modeling covariance structure in the analysis of repeated measures data. Statistics in Medicine 19: 1793-1819.

Mezzalira, J.C.; Carvalho, P.C.F.; Fonseca, L.; Bremm, C.; Cangiano, C.; Gonda, H.L.; Laca, E.A. 2014. Behavioural mechanisms of intake rate by heifers grazing swards of contrasting structures. Applied Animal Behaviour Science 153: $1-9$. 
Pereira, J.C.; Gomes, F.K.; Oliveira, M.B.D.L.; Lara, M.A.S.; Bernardes, T.F.; Casagrande, D.R. 2017. Defoliation management affects morphogenetic and structural characteristics of mixed pastures of brachiaria grass and forage peanut. African Journal of Range \& Forage Science 34: 13-19.

Ribeiro Filho, H.M.N.; Delagarde, R.; Peyraud, J.L. 2003. Inclusion of white clover in strip-grazed perennial ryegrass swards: herbage intake and milk yield of dairy cows at different ages of sward regrowth. Animal Science 77: 499-510.

Silveira, M.C.T.; Nascimento Júnior, D.; Rodrigues, C.S.; Pena, K.S.; Souza, S.J.; Barbero, L.M.; Limão, V.A.; Euclides, V.P.B.; Silva, S.C. 2016. Forage sward structure of Mulato grass (Brachiaria hybrid ssp.) subjected to rotational stocking strategies. Australian Journal of Crop Science 10: 864-873.

Spalinger, D.E.; Hobbs, N.T. 1992. Mechanisms of foraging in mammalian herbivores: new models of functional response. The American Naturalist 140: 325-348.
Stobbs, T.H. 1973. The effect of plant structure on the intake of tropical pastures. II. Differences in sward structure, nutritive value, and bite size of animals grazing Setaria anceps and Chloris gayana at various stages of growth. Australian Journal of Agricultural Research 24: 821-829.

Tamele, O.H.; Sá, O.A.A.L.; Bernardes, T.F.; Lara, M.A.S.; Casagrande D.R. 2018. Optimal defoliation management of brachiaria grass-forage peanut for balanced pasture establishment. Grass and Forage Science 73: 522-531.

Tsutsumi, M.; Takahashi, Y.; Emoto, S.; Ito, N.; Otani, I.; Matsumoto, K. 2016. Component-based quantification and prediction of diet selection by cattle grazing on multi-species communities. Grassland Science 62: 12-20.

Vries, M.F.W. 1995. Estimating forage intake and quality in grazing cattle: a reconsideration of the hand-plucking method. Journal of Range Management 48: 370-375. 